\title{
ANALISIS FUNGSI PRODUKTIVITAS DAN FUNGSI PENDAPATAN USAHATANI JAGUNG ARJUNA DI DESA MULYO AGUNG KECAMATAN DAU KABUPATEN MALANG
}

\section{ANALYSIS OF PRODUCTIVITY AND INCOME FUNCTION OF ARJUNA CORN FARMING IN MULYO AGUNG VILLAGE THE DISTRICT OF DAU MALANG}

\author{
Andria Pereira Joan ${ }^{1}$, Iwan Nugroho ${ }^{1}$, Suwarta $^{1}$ \\ 1) Fakultas Pertanian Universitas Widyagama Malang \\ Email : suwarta78@ymail.com
}

\begin{abstract}
ABSTRAK
Tujuan penelitian ini adalah untuk: a. mengetahui faktor-faktor yang mempengaruhi produktivitas usahatani jagung Arjuna, b. mengetahui faktor-faktor yang mempengaruhi pendapatan usahatani jagung Arjuna. Lokasi penelitian di desa Mulyo Agung, Kecamatan Dau, Kabupaten Malang. Pemilihan lokasi penelitian dilakukan secara sengaja dengan pertimbangan bahwa daerah tersebut termasuk salah satu penghasil jagung Arjuna di Malang. Jenis data yang digunakan adalah data primer dan data sekunder. Alat analisis menggunaan model regeresi liniar berganda dalam bentuk natural. Hasil penelitian menunjukkan bahwa: 1. Pupuk urea berpengaruh positif terhadap produktivitas usahatani jagung Arjuna. Sementara itu variabel lain, yaitu bibit, pestisida, jumlah tenaga kerja dan luas lahan, tidak berpengaruh terhadap produktivitas usahatani jagung arjuna. 2. Pendapatan usahatani jagung Arjuna dipengaruhi secara negatif oleh upah tenaga kerja dan pajak. Sementara itu, pendapatan usahatani jagung Arjuna dipengaruhi secara positif oleh umur petani.
\end{abstract}

Kata kunci: Faktor-faktor, pendapatan, produktivitas, usahatani Jagung Arjuna

\begin{abstract}
The purposes of this research were: a. to know the factors that influence productivity of Arjuna corn farming, $b$. to know the factors that influence the income of Arjuna maize farming. Research location was in Mulyo Agung village, Dau district, Malang regency. The selection of research sites was done deliberately with the consideration that the area is one of the producers of Arjuna corn in Malang. The type of data used is primary data and secondary data. The analytical tool uses multiple linear regression models in natural form. The results showed that: 1 . Fertilizer urea positively affect the productivity of arjuna corn farming. While other variables, namely seeds, pesticides, the amount of labor and land area, does not affect the productivity of arjuna maize farming. 2. Arjuna corn farm income is negatively affected by labor and tax wages. Meanwhile, the income of arjuna maize farming is positively influenced by the age of farmers. For arjuna maize farming to produce higher productivity and income, it needs to be improved in managing the factors that influence it.
\end{abstract}

Keywords : Arjuna maize farming, factors, productivity, revenue 


\section{PENDAHULUAN}

Peranan sektor pertanian dalam perekonomian Indonesia secara umum adalah: (1) Pembentuk Produk Domestik Bruto (PDB); (2) Salah satu sumber penghasil devisa; (3) Penyedia pangan penduduk dan bahan baku bagi industri; (4) Salah satu sektor yang dapat mengentaskan masalah kemiskinan; (5) Penyedia lapangan kerja; (6) Salah satu sumber peningkatan pendapatan masyarakat; dan (7) Salah satu sumber peman tapan ketahanan pangan nasional (Hafzrianda, et al., 2012).

Pengembangan sektor pertanian merupakan syarat mutlak untuk dapat meningkatkan taraf hidup masyarakat. Hal tersebut tercermin dari kebijakan pemerintah, di mana pertanian tetap ditempatkan pada prioritas utama. Sektor pertanian meliputi sub-sektor tanaman bahan makanan, sub-sekor hultikultura, sub-sektor perikanan, sub-sektor peternakan dan sub-sektor kehutanan.

Sub-sektor tanaman bahan makanan mendapatkan perhatian lebih. Kebutuhan bahan pangan akan selalu bertambah seiring dengan semakin meningkatnya jumlah penduduk. Pangan berasal dari sumber daya hayati dan air, baik yang diolah maupun tidak diolah, yang diperuntukkan sebagai makanan dan minuman bagi manusia termasuk bahan tambahan pangan, bahan baku pangan dan bahan lain yang diguna kan dalam proses penyiapan, pengolahan dan pembuatan makanan atau minuman.

Salah satu komoditas pertanian yang termasuk dalam sub-sektor tanaman bahan makanan adalah jagung. Jagung (Zea mays L) merupakan salah satu komoditas pertanian yang sangat penting. Selain dikonsumsi dalam bentuk sayuran, juga dapat diolah menjadi aneka makanan untuk mencukupi kebutuhan industri. Selain itu, juga merupakan salah satu serealia yang strategis dan bernilai ekonomi, mempunyai peluang besar untuk dikembangkan, dan kedu dukannya sebagai sumber utama karbohidrat dan protein setelah beras.

Jagung di Jawa Timur produktivitasnya masih relatif rendah yaitu 2,58 ton pipilan kering per hektar. Lebih dari $75 \%$ daerah produksi jagung di Jawa Timur terdapat di lahan kering dengan tingkat kesuburan tanah dan iklim yang beragam. Realisasi produksi 
jagung Subround I 2014 di beberapa kabupaten atau kota di Jawa Timur ada yang mengalami kenaikan atau penurunan bila dibandingkan dengan sub round yang sama tahun sebelumnya.

Di Jawa Timur, kabupaten yang mengalami kenaikan produksi jagung dalam katagori besar, antara lain: a. Kabupaten Ngawi naik 28,31 ribu ton pipilan kering $(55,41 \%)$, b. Kabupaten Lamongan naik 20,68 ribu ton pipilan kering $(19,91 \%)$, c. Kabupaten Pasuruan naik 14,06 ribu ton pipilan kering $(22,51 \%)$, d. Kabupaten Gresik naik 13,04 ribu ton pipilan kering $(28,46 \%)$, dan e. Kabupaten Pamekasan naik 12,26 ribu ton pipilan kering (15,69\%). Sementara itu, kabupaten yang mengalami penurunan produksi jagung dalam jumlah yang besar, antara lain Kabupaten Ponorogo turun 41,01 ribu ton pipilan kering ($27,04 \%)$, Kabupaten Sumenep turun 34,38 ribu ton pipilan kering (11,54\%) (BPS Jawa Timur, 2015).

Di Kabupaten Malang produksi jagung mengalami penurunan 1,20 ton pipilan kering (-19,75\%), Kabupaten Situbondo turun 26,55 ribu ton pipilan kering (-20,58\%), dan Kabupaten Lumajang turun 18,04 ribu ton pipilan kering $\quad(-40,96 \%)$. Menurunnya realisasi produksi jagung pada Subround I 2014 sebesar 5,02\% dibandingkan dengan Subround I 2013, hal ini disebabkan karena beberapa kabupaten mengalami penurunan produksi, antara lain: a. Kabupaten Ponorogo terjadi perpindahan pola tanam dari jagung ke tanaman padi dan kedelai, produktivitas jagung mengalami penurunan karena ketersediaan pupuk (Urea, SP 36, dan ZA) pada saat dibutuhkan oleh petani tidak tersedia, di Kabupaten Malang terjadi perpindahan pola tanam dari jagung ke tanaman tebu.

Aktifitas usahatani yang lebih baik dapat dilihat dari adanya peningkatan-peningkatan dalam produktivitas usahatani yang pada gilirannya akan meningkatkan pendapatan petani sehingga akan mendukung terciptanya kesejahteraan yang lebih baik bagi petani dan keluarganya. Oleh karena itu perlu adanya upaya untuk meningkatkan produk tivitas dan pendapatan usahatani jagung, termasuk jagung Arjuna.

Desa Mulyoagung merupakan daerah yang terletak pada kawasan 
lereng gunung yang beriklim sejuk dengan suhu rata-rata $20^{\circ} \mathrm{c}$, ada di Kecamatan Dau Kabupaten Malang. Dengan kondisi tersebut menjadikan Desa Mulyoagung terkenal dengan pertaniannya karena iklim yang cocok untuk usaha pertanian yang beragam seperti jagung, sayur-sayuran yang hidup di suhu yang dingin. Keberlimpahan potensi tersebut menjadi faktor pendorong bagi petani di desa Mulyoagung untuk terus berinovasi dan mengembangkan potensi yang dimiliki untuk pengembangan jasa perdagangan, industri dan parawisata karena didukung oleh posisi startegis yang merupakan wilayah di antara dua perkotaan yakni Kota Malang dan Kota Batu.

Berdasarkan latar belakang masalah di atas maka dalam tulisan ini mengambil tema yang berjudul "Analisis Produktivitas dan Pendapatan Usahatani Jagung Arjuna di desa Mulyoagung kecamatan Dau kabupaten Malang". Dengan model produktifitas dan pendapatan usaha tani jagung Arjuna diharapkan dapat dipakai sebagai tambahan informasi dalam rangka untuk meningkatkan produktivitas dan pendapatan usaha tani jagung Arjuna, sehingga usaha target jumlah produksi dan pening katan pendapatan dapat tercapai.

\section{METODE PENELITIAN}

Lokasi penelitian dilakukan di Desa Mulyo Agung, Kecamatan Dau, Kabupaten Malang. Pemilihan lokasi penelitian dilakukan secara sengaja dengan pertimbangan bahwa desa tersebut termasuk salah satu desa penghasil jagung dalam jumlah banyak.

Data yang digunakan dalam penelitian ini adalah data primer dan data sekunder. Data primer diperoleh melalui wawancara langsung dengan petani sampel dengan jumlah 30 petani. Penggalian data dilakukan dengan menggunakan daftar pertanyaan yang telah disiapkan. Data yang diambil meliputi Identitas petani, antara lain: umur petani, pendidikan petani, pengalaman petani, dan lain nya, data mengenai usahatani jagung, antara lain: produksi dan harganya, faktor produksi dan harganya. Sedangkan data sekuder merupakan data yang diperoleh atau dikumpulkan dari Badan Pusat Statistik (BPS), instansi tertentu yang terkait dengan masalah yang akan diteliti, 
perpustakaan atau dari jurnal-jurnal, dan laporan-laporan penelitian terdahulu.

\section{Metode Analisis}

Analisis Regeresi Linier Berganda

Analisis untuk menguji hipotesis, diuji dengan menggunakan analisis regeresi linier berganda dengan rumus:

\section{Produktivitas}

\section{Model :}

$\operatorname{Ln} Y=\operatorname{Ln} a_{0}+a_{1} \operatorname{Ln} X_{1}+a_{2} \operatorname{Ln} X_{2}+a_{3} \operatorname{Ln} X_{3}+a_{4} \operatorname{Ln} X_{4}+a_{5} \operatorname{Ln} X_{5}+a_{6} \operatorname{Ln} X_{6}$

$$
+\mathrm{a}_{7} \operatorname{LnX} \mathrm{X}_{7}+\mathrm{a}_{8} \operatorname{LnX} X_{8}+\mathrm{a}_{9} \operatorname{Ln} \mathrm{X}_{9}+\mathrm{a}_{10} \operatorname{Ln} \mathrm{X}_{10}+\mathrm{ui}
$$

Keterangan :

$\mathrm{Y}=$ Produktivitas (ton/hekatar)

$\mathrm{X}_{1}=$ Bibit $(\mathrm{kg})$

$\mathrm{X}_{2}=$ Pupuk urea $(\mathrm{kg})$

$\mathrm{X}_{3}=$ Pestisida $(\mathrm{Ltr} / \mathrm{cc})$

$\mathrm{X}_{4}=$ Pupuk SP-36 $(\mathrm{kg})$

Model dianalisis dengan program SPSS. Model produktivitas usahatani jagung Arjuna yang dianalisis diharapkan dapat diperoleh model yang baik. Dengan model tersebut dapat diuji baik secara keseluruhan maupun secara parsial. Uji secara keseluruhan ditentukan oleh
$\mathrm{X}_{5}=$ Pupuk KCI (kg)

$\mathrm{X}_{6}=$ Tenaga Kerja (HKO)

$\mathrm{X}_{7}=$ Luas Lahan (ha)

$\mathrm{X}_{8}=$ Umur Petani (th)

$\mathrm{X}_{9}=$ Tingkatan Pendidikan (th)

$\mathrm{X}_{10}=$ Pengalaman Kerja (th)

nilai $\mathrm{R}^{2}$ dan (F-test). Model dikatakan baik apabila nilai $\mathrm{R}^{2}$ mendekati $100 \%$, atau 0,99 atau $99 \%$. F-test secara statistik nyata, artinya semua independen variabel $\left(\mathrm{x}_{1}, \ldots \mathrm{x}_{10}\right)$ berpengaruh terhadap variabel dependen (Produksi).

\section{Pendapatan}

\section{Model :}

$\operatorname{Ln} I^{*}=b_{0}+b_{1} \operatorname{Ln} \operatorname{Px}_{1}{ }^{*}+b_{2} \operatorname{Ln} \operatorname{Px}_{2}{ }^{*}+b_{3} \operatorname{Ln~Px}_{4}{ }^{*}+u i$

Keterangan :

$\mathrm{I}^{*}$ : Pendapatan riil (jumlah pendapatan dibagi dengan harga produksi)

Model dianalisis dengan program SPSS. Model pendapatan
$\mathrm{Px}_{1}{ }^{*}=$ Harga bibit riil $(\mathrm{Rp})$

$\mathrm{Px}_{2}{ }^{*}=$ Harga Pestisida riil (Rp)

$\mathrm{Px}_{3}{ }^{*}=$ Harga Pupuk riil $(\mathrm{Rp})$

$\mathrm{Px}_{4}{ }^{*}=$ Upah tenaga kerja riil $(\mathrm{Rp})$

usahatani jagung Arjuna yang dianalisis diharapkan dapat diperoleh 
model yang baik. Dengan model tersebut dapat diuji baik secara keseluruhan maupun secara parsial. Uji secara keseluruhan ditentukan oleh nilai $\mathrm{R}^{2}$ dan (F-test). Model dikatakan baik apabila nilai $\mathrm{R}^{2}$ mendekati $100 \%$, atau 0,99 atau $99 \%$. F-test secara statistik nyata, artinya semua indepen den variabel $\left(\mathrm{x}_{1}, \ldots \mathrm{x}_{10}\right)$ berpengaruh terhadap variabel dependen (penda patan).

\section{HASIL DAN PEMBAHASAN}

\section{Fungsi Produktivitas Usahatani Jagung Arjuna}

Hasil penelitian (Tabel 1) menunjukan bahwa uji secara bersama-sama nilai $\mathrm{R}^{2}=0,704$, artinya $70,4 \%$ produktivitas usahatani jagung Arjuna dipengaruhi oleh variabel independen dalam model.
Sementara itu, produktivitas usaha tani jagung Arjuna 29,6\% dipengaruhi oleh variabel independen di luar model. Nilai $F$-test $=11,419(\alpha=1 \%)$ mempunyai arti bahwa variabel independen dalam model secara bersama-sama berpengaruh terhadap produktivitas usahatani jagung Arjuna.

Secara parsial, hanya pupuk urea yang berpengaruh terhadap produktivitas usahatani jagung Arjuna. Pupuk urea berpengaruh positif terhadap produktivitas sahatani jagung arjuna dengan elastisitas $0,318 \quad(\alpha$ $10 \%$ ), artinya apabila pupuk urea ditambah dengan $10 \%$ mengakibatkan produktivitas usaha tani jagung arjuna bertambah 3,19\% sebaliknya apabila pupuk urea dikurangi $10 \%$ mengakibatkan produk tivitas jagung Arjuna turun 3,19\%.

Tabel 1. Hasil Analisis Regresi Linier Berganda pada Produktivitas

\begin{tabular}{lccrc}
\hline Variabel & Koefisien & $\begin{array}{c}\text { Standardized } \\
\text { Coeffisient }\end{array}$ & Tstatistic & Prob. \\
\hline Konstanta & 1,046 & & 0,305 & 0,763 \\
Bibit & $-1,163$ & $-0,783$ & $-1,038$ & 0,310 \\
Pupuk Urea & $1,318^{*}$ & 0,798 & 1,736 & 0,095 \\
Pestisida (Cidro metrin) & $-0,013$ & $-0,014$ & $-0,085$ & 0,933 \\
Jumlah Tenaga Kerja & 0,915 & 0,565 & 1,225 & 0,233 \\
Luas Lahan & 0,370 & 0,313 & 0,479 & 0,636 \\
\hline Fstatistic $=11,419 * * *$ & Prob & $=0,000$ \\
R-squared $=0,704 \quad$ Adj. R-squared & $=0,642$ \\
Keterangan : *** =nyata pada $\alpha=1 \%, *=$ nyata pada $\alpha=10 \%$ \\
Sumber: Data primer diolah 2016
\end{tabular}


Variabel independen yang lain, yaitu jumlah bibit, pestisida, julah tenaga kerja dan luas lahan tidak berpengaruh terhadap produktivitas usahatani jagung Arjuna. Namun demikian, jumlah bibit cenderung berpengaruh negatif, pestisida cenderung berpengaruh negatif, jumlah tenaga kerja cenderung berpengaruh positif, dan luas lahan cenderung berpengaruh positif. Namun demikian semua variabel independen tersebut secara statisitik tidak nyata.

Yull (2014), menyatakan bahwa jenis bibit, jumlah pestisida, dan jumlah tenaga kerja berpengaruh positif terhadap produksi jagung. Awiyanto (2014), produksi usahatani jagung dipengaruhi tenaga kerja, pupuk, dan pestisida berpe ngaruh negatif terhadap produksi jagung.

\section{Fungsi Pendapatan Usahatani Jagung Arjuna}

Hasil analisis (Tabel 2) menunjukkan bahwa nilai $\mathrm{R}^{2}=0,751$, artinya pendapatan usahatani jagung Arjuna $75,1 \%$ dipengaruhi oleh variabel independen dalam model. Sementara itu, pendapatan usahatani jagung Arjuna 24,9\% dipengaruhi oleh variabel independen di luar model. Nilai F-statistik 9,50 ( $\alpha=1 \%)$ artinya variabel independen dalam model secara bersama-sama berpengaruh terhadap pendapatan usahatani jagung Arjuna.

Tabel 2. Hasil Analisis Regresi Linier Berganda pada pendapatan, 2016

\begin{tabular}{|c|c|c|c|c|}
\hline Variabel & Koefisien & $\begin{array}{c}\text { Standardized } \\
\text { Coeffisient }\end{array}$ & Tstatistic & Prob \\
\hline Konstanta & $27,437 * * *$ & & 3,011 & 0,006 \\
\hline Harga bibit riil (Rp) & $1,480-\mathrm{ns}$ & 1,168 & 1,065 & 0,298 \\
\hline Harga pestisida riil (Rp) & $0,618-\mathrm{ns}$ & 0,520 & 0,819 & 0,422 \\
\hline Harga pupuk riil (Rp) & $-1,686-\mathrm{ns}$ & $-1,216$ & $-1,325$ & 0,199 \\
\hline Upah tenaga kerja $(\mathrm{Rp})$ & $-2,283^{*}$ & $-1,409$ & $-1,952$ & 0,064 \\
\hline Pajak (Rp) & $-3,442 * *$ & $-1,135$ & $-2,277$ & 0,033 \\
\hline Umur petani (Tahun) & $1,104 *$ & 0,198 & 1,738 & 0,096 \\
\hline Lama pendidikan (Tahun) & 0,236 & 0,142 & 1,139 & 0,267 \\
\hline Fstatistic & $=9,500 * * *$ & Prob & $=0,000$ & \\
\hline R-squared & $=0,751$ & Adj. R-squared & $=0,672$ & \\
\hline
\end{tabular}


independen yang berpengaruh negatif terhadap pendapatan usahatani jagung Arjuna adalah upah tenaga kerja dan pajak. Sementara itu, umur petani berpengaruh positif terhadap pendapatan usahatani jagung Arjuna. Variabel lain, meliputi harga bibit, harga pupuk, harga pestisida dan tingkat pendidikan petani tidak berpengaruh terhadap pendapatan usahatani jagung hibrida.

Upah tenaga kerja. Variabel upah tenaga kerja berpengaruh negatif terhadap pendapatan usahatani jagung Arjuna dengan elastisitas $-2,283^{*}(\alpha=$ 10\%). Hasil tersebut menunjukkan bahwa setiap kenaikan upah tenaga kerja $10 \%$ mengakibatkan pendapatan usahatani jagung Arjuna turun $22,83 \%$. Sebaliknya, setiap penurunan upah tenaga kerja 10\% mengakibatkan pendapatan usahatani jagung Arjuna naik $22,83 \%$.

Besaran pajak. Pajak berpengaruh negatif terhadap pendapatan usahatani jagung Arjuna dengan elastisitas $-3,442 * *(\alpha=5 \%)$. Hasil tersebut menunjukkan bahwa setiap kenaikan pajak $1 \%$ mengakibatkan pendapatan usahatani jagung Arjuna turun 3,44\%. Sebaliknya, besaran pajak turun $1 \%$ mengakibatkan pendapatan usahatani jagung Arjuna naik 3,44\%.

Umur petani. Umur petani berpengaruh positif terhadap pendapatan usahatani jagung Arjuna dengan elastisitas $1,104 *(\alpha=10 \%)$. Hasil tersebut menunjukkan bahwa apabila umur petani bertambah $1 \%$ mengakibatkan pendapatan bertambah $1,10 \%$, dan sebaliknya apabila umur berkurang $1 \%$ mengakibatkan pendapatan berkurang $1,10 \%$.

Yull (2014), menyatakan bahwa pendapatan usahatani jagung dipengaruhi oleh harga jual jagung, biaya lahan, biaya bibit, biaya pupuk, upah tenaga kerja. Sementara itu, Awiyanto (2014), menyatakan bahwa jumlah produksi, biaya benih dan harga jual jagung berpengaruh positif terhadap pendapatan. Sebaliknya, biaya pestisida dan biaya tenaga kerja berpengaruh negatif terhadap pendapatan usaha tani jagung.

\section{KESIMPULAN DAN SARAN}

\section{Kesimpulan}

Produktivitas usahatani jagung Arjuna dipengaruhi secara positif oleh jumlah pupuk urea. Sementara itu, variabel lain yaitu jumlah bibit, pestisida, jumlah tenaga kerja dan 
luas lahan tidak berpengaruh secara nyata terhadap produktivitas usahatani jagung Arjuna.

Pendapatan usahatani jagung Arjuna dipengaruhi secara negatif oleh upah tenaga kerja dan jumlah pajak, tetapi dipengaruhi secara positif oleh umur petani. Sementara itu, faktor harga bibit, harga pestisida dan harga pupuk tidak berpengaruh secara nyata terhadap pendapatan usahatani jagung arjuna.

\section{Saran}

Petani perlu memperhatikan
faktor-faktor yang mempengaruhi
proses produksi dan faktor-faktor yang
mempengaruhi tercapainya
pendapatan yang lebih baik.

\section{DAFTAR PUSTAKA}

Awiyanto. 2014. Faktor-Faktor yang Mempengaruhi Produksi Jagung di Kabupaten Sumenep. https://www.Researchgate.Net/Pu blication/

Bambang C. 2007. Jagung, Tehnik Budidaya dan Analisis Usahatani. Aneka Ilmu. Semarang.

Berita Resmi Statistik Provinsi Jawa Timur, No.47/07/35/Th.XIII,1 Juli 2015 http://agris.fao.org/agrissearch/search.do?recordID=ID199 70140991.
Gunjarati, N.D. 2006. Dasar-dasar Ekonometrika Jilid 1. Erlangga. Jakarta.

Hafzrianda, Y., C.M. Bisai dan A.R. Pajeru. 2012. Analisis Pertumbuhan dan Potensi Sektoral.

Nicholson, W. 1999. Teori Ekonomi Mikro Prinsip Dasar dan Pengembangannya. Cetakan Kelima. Raja Grafindo Persada. Jakarta.

Purwanto, S. 2007. Perkembangan Produksi dan Kebijakan dalam Peningkatan Produksi Jagung.

Ravianto, J. 1985. Produktivitas dan Manajemen SIUP . Jakarta

Rukmana, R. H. 2007. Budidaya dan pasca panen jagung. Aneka Ilmu. Semarang.

Sudaryanto. 1991. Kajian Analisis Usahatani di Ciawi. Materi Pelatihan Dasar II. 12 April 1991. Ciawi. Bogor.

Soekartawati. 2002. Prinsip-prinsip Dasar Manajemen Pemasaran dan Hasil-Hasil Pertanian (teori dan aplikasi). Raja Grafindo. Jakarta.

Soekartawi. 1990. Teori Ekonomi Produksi, dengan Pokok Bahasan Analisis Fungsi Cobb-Douglas. Rajawali Press. Jakarta.

Soekartawi. 1986. Ilmu Usahatani dan Penelitian Untuk Pengembangan Pertanian. UI-Press. Jakarta. 
Sumiarti, M. 1997. Dasar-dasar Ekonomi Perusahaan. Edisi II. Liberty. Yogyakarta.

Yull, A. R. N. 2014. Faktor-Faktor yang Mempengaruhi Produksi dan Pendapatan Petani Jagung (Studi Kasus: Desa Lau Bakeri, Kec. Kuta Limbaru, Kab. Deli Serdang). http://repository.usu.ac.id/bitstrea m/handle/. 